\title{
LAISVALAIKIU BESIMANKŠTINANČIŲ ASMENŲ MAISTO PAPILDŲ, MAŽINANČIŲ KŪNO MASE, VARTOJIMAS: SUSIJUSIŲ VEIKSNIŲ ANALIZE்
}

\author{
Rasa Jankauskienė, Ramutis Kairaitis \\ Lietuvos kūno kultūros akademija, Kaunas, Lietuva
}

\begin{abstract}
Rasa Jankauskienė. Docentė socialinių mokslų daktarẻ. Lietuvos kūno kultūros akademijos Sveikatos ir fizinio aktyvumo katedros vedèja. Mokslinių tyrimų kryptis — ivvairaus amžiaus žmonių kūno masès kontrolè ir su fiziniu aktyvumu susijęs elgesys.
\end{abstract}

\section{SANTRAUKA}

Maisto papildu, mažinančiu kūno masę, vartojimas gali būti žalingas sveikatai dèl abejotino kai kuriu preparatu veiksmingumo ir saugumo. Nepaisant to, nuo 7 iki 33\% amerikiečiu yra bent karta gyvenime vartojęs šiuos preparatus. Ju vartojimo paplitimas besimankštinančiu populiacijose nežinomas, nors yra studiju, nurodančiu, kad kas antras sportuotojas vartoja maisto papildus. Tyrimu, nagrinejančiu šiu maisto papildu vartojimo paplitima, yra nepakankamai, dar mažiau ju atlikta analizuojant šiu preparatu vartojimo ryšius su mankštinimosi motyvacijos, tikslu ir nerimo dèl socialinio išvaizdos priemmimo veiksniais. Tyrimo tikslas - nustatyti sveikatingumo centruose besimankštinančiv asmenu maisto papildu mažinanči kūno mase vartojimo paplitimq ir atlikti susijusiu veiksni乇 analizę.

Tyrimas buvo atliekamas 11 šalies sveikatingumo centru, taikant anketavimo metoda. Išanalizuoti 217 tiriamuju (iš ju—66 moterys) duomenys, amžiaus vidurkis - 29,02 $\pm 9,9$ m. Anketq sudare demografiniu, su mankštinimusi ir kūno mase mažinanči u maisto papildu (MP) vartojimu susijusiu klausimu blokas. Mankštinimosi motyvai buvo nustatomi remiantis klausimynu (angl. Motives for Physical Activity Measure - Revised, MPAM - R) (Frederick, Ryan, 1993). Nerimas dèl socialinio išvaizdos prièmimo (NSIP) buvo nustatytas Nerimo dèl socialinio išvaizdos prièmimo skale (angl. Social Physique Anxiety Scale) (Hart et al., 1989).

Iš visos tiriamosios imties MP per pastaruosius du mènesius vartojo $16,3 \%$ respondentu, daugiau moteru negu vyru $(p=0,01)$. Išoriniai mankštinimosi motyvai nebuvo susiję su dažnesniu maisto papildu vartojimu. Logistinè regresiné analizè atskleidè, kad kontroliuojant lyties efekta NSIP ir mankštinimosi dèl riebalu mažinimo tikslas buvo susiję su dažnesniu maisto papildu vartojimu ( $p<0,05)$.

Besimankštinantys asmenys kūno masę kontroliuoja sveikatai žalingu būdu, todèl būtina stiprinti jo prevencija mažinant besimankštinančiu asmenu nerima dèl socialinio išvaizdos prièmimo ir mankšstinimosi dèl riebalu mažinimo motyvu sureikšminima. Rezultatu negalima apibendrinti dèl mažos tiriamuju imties, reikalingi tolesni tyrimai.

Raktažodžiai: maisto papildai, mankštinimosi motyvai, nerimas dèl socialinio išvaizdos prièmimo.

\section{IVADAS}

$\mathrm{P}$ opuliaciniai tyrimai atskleidžia, kad asmenys, kurie dažniau vartoja vitaminus ir mineralus, yra labiau išsilavinę, turi mažesni kūno masès indeksą, dažniau priskiriami nerūkančiuju grupei ir dažniau laisvalaikiu mankštinasi (Reinert et al., 2007). Deja, kokybiniai tyrimai atskleidžia, kad laisvalaikiu sveikatingumo centruose besimankštinantys asmenys linkę pernelyg gausiai vartoti ịvairius maisto papildus, ypač ne vitaminus ir mineralus, kurie padeda priaugti raumenų masès arba atsikratyti kūno riebalų (Atkinson, 2007). Ištyrus 1482 JAV jūreivius nustatyta, kad 21\% vartojo mažiausiai keturis maisto papildus vienu metu, o $51 \%$ papildus, kurių sudètyje yra efedrino (Castillo et al., 2002). Tiriant studentus nustatyta, $\operatorname{kad} 71,1 \%$ studentų maisto papildus (ne vitaminus 
ir mineralus) vartoja norèdami mažinti kūno svori, $8,4 \%$ iš juos vartojančiujų teige jaučiantys pašalini poveiki (Ayranci et al., 2005). Moterys dažniau maisto papildus vartoja dèl savo sveikatos arba dèl nevisavertès mitybos, vyrai - dèl fizinès būklès gerinimo (Froiland et al., 2004).

Apžvalginiai tyrimai atskleidžia, kad šiuo metu svoriui mažinti sukurta ir reklamuojama apie penkios dešimtys įvairių maisto papildų. Sveikatos profesionalai nesutaria dèl jų saugumo ir veiksmingumo, todèl jų vartoti mažinant svori yra nerekomenduotina (Lenz, Hamilton, 2004). Daugelyje maisto papildų, skirtų kūno masei mažinti, yra stimuliatorių, kurių ilgalaikis vartojimas gali sukelti rimtą pavojų sveikatai ir nerekomenduotinas be gydytojo konsultacijos. Šalyje populiariausiais kūno masę mažinančiais papildais laikomos riebalus deginančios medžiagos — kofeinas ir L-karnitinas. Pavyzdžiui, JAV $15,2 \%$ suaugusių žmonių ( $20,6 \%$ moteru ir $9,7 \%$ vyru) bent karta gyvenime vartojo maisto papildus. Daugiausia maisto papildų vartojo moterys nuo 18 iki 34 metų amžiaus. Vienas iš dešimties vartojančiujų tai darè ilgiau negu 12 mènesių, tarp jų buvo daugiau vyru. $73,8 \%$ vartojo maisto papildus, savo sudètyje turinčius stimuliatoriu (kofeino, efedros arba karčiojo apelsino) (Blank et al., 2007).

1992 metais ištyrus 12 populiariausiu sveikatos ir kultūrizmo žurnalų reklamuojamų maisto papildų buvo rasta, kad $22 \%$ maisto papildų neturejo tų medžiagų, kurios buvo įrašytos etiketèse, o jų vietoje aptikta kitu, neminimų medžiagu (Philen et al., 1992). 1993 metais nustatyta, kad 624 maisto papildų, reklamuojamų kultūristams, poveikis nebuvo paremtas mokslinèmis studijomis (Grunewald, Bailey, 1993). Tyrimai atskleidžia, kad žoliniai kūno masę mažinantys maisto papildai, kurių sudètyje yra efedros, turi dideli pašalini poveiki — gali pasireikšti psichiniai, žarnyno ir kiti sutrikimai (Pittler et al., 2005).

Apklausus 511 treniruoklių salių klientų nustatyta, kad per pastaruosius trejus metus net $25 \%$ vyrų ir 13\% moterų vartojo efedriną (Kanayama et al., 2001). İdomu tai, kad kūno įvaizdžio medikamentai pradedami vartoti jau paauglystèje. Pavyzdžiui, apklausus 4237 paauglius nuo 12 iki 17 metú nustatyta, kad 4,7\% berniukų ir 1,6\% mergaičių vartojo proteinu kokteilius, kreatina, aminorūgštis / HMB, dehydroepiandrosteroną, augimo hormoną ar leidžiamus anabolinius steroidus ne mažiau kaip kartą per savaitę, norėdami gerinti savo išvaizdą arba didinti jègą (Field et al., 2005). Tyrimai atskleidžia, kad, pavyzdžiui, kofeiną, kuris padeda mažinti svori, vartojo puse sveikatingumo centru sportuotoju (Sheppard et al., 2000).

Maža to, 37,5-69\% besimankštinančių ergogenines priemones ir maisto papildus vartoja konsultuojami draugu ir trenerių (instruktorių), skaitydami juos populiarinančius žurnalus, žiūredami TV (Sheppard et al., 2000; Ayranci et al., 2005; Kristiansen et al., 2005; Domingues, Marins, 2007). Kiti tyrimai atskleidžia, kad sportininkų maisto papildų vartojimo dažnumas tiesiogiai susijęs su valandų, praleistų treniruoklių salèse, kiekiu (Raudenbush, Meyer, 2003).

Kūno svorị dažniau mažina ir valgymo patologijos problemų turi tie asmenys, kurie juo yra nepatenkinti ir / ar dažniau jaučia nerimą dèl to, kaip jų išvaizdą priima kiti asmenys (Diehl et al., 1998). Šis fenomenas vadinamas nerimu dèl socialinio išvaizdos prièmimo (NSIP). Nustatyta, kad asmenys, nepatenkinti savo kūno svoriu, dažniau mankštinasi dèl išvaizdos gerinimo motyvų, o ši motyvacija siejama su didesniu NSIP (Sabiston et al., 2005). Remiantis minètais tyrimais galima kelti prielaida, kad asmenys, kurie labiau išgyvena dèl socialinio išvaizdos prièmimo, dažniau vartos maisto papildus, mažinančius kūno masę.

Pastaruoju metu atlikta nemažai tyrimų, kuriais nustatomas įvairių maisto papildų vartojimo paplitimas, tačiau tokių, kurie tyrinètu motyvacinius šio elgesio veiksnius, atlikta mažiau (Lutz, Arent, 2009). Nèra iki galo žinoma, kaip mankštinimosi motyvacija (išorinė ir vidinè), mankštinimosi tikslai, kūno masės indeksas, NSIP yra susiję su maisto papildų, mažinančių kūno masę, vartojimu. Šiuo tyrimu kèlème prielaidą, kad kūno masę mažinančius papildus dažniau vartos moterys, jaunesni besimankštinantys asmenys, kurie tai daro dèl išvaizdos gerinimo motyvų, ir norintys sumažinti riebalų kiekį. Taip pat tikejjomès, kad kūno masę mažinančius maisto papildus dažniau vartos asmenys, dažniau išgyvenantys NSIP.

Todèl šiuo tyrimu kèlème tikslą - nustatyti sveikatingumo centruose besimankštinančiu asmenų maisto papildų, mažinančių kūno masę, vartojimo paplitimą ir atlikti susijusių veiksnių analizę.

\section{TYRIMO METODIKA}

Anketą sudarè demografinių klausimų (respondentų buvo prašoma nurodyti savo amžių ir lyti), ir su mankštinimusi susijusių klausimų (prašoma 
nurodyti savo mankštinimosi stažą metais, mankštinimosi tikslą ir kitus su mankštinimusi susijusius duomenis) blokai.

Maisto papildų, kurie mažina kūno masę, vartojimas buvo nustatytas klausimu: Ar per pastaruosius du ménesius vartojote šiuos maisto papildus? Galimi atsakymo variantai: medžiagas, deginančias riebalus, kofeiną, karnitiną ir kt. (prašoma nurodyti nepaminètu maisto papildų rūši ). Toliau tiriamuju buvo prašoma nurodyti, kaip dažnai šie maisto papildai buvo vartojami per pastaruosius du mènesius.

Mankštinimosi motyvai buvo nustatomi apsisprendimo teorijos pagrindu sukurtu klausimynu (angl. Motives for Physical Activity Measure - Revised, MPAM - R) (Frederick, Ryan, 1993). Šio tyrimo metu buvo naudojamos trys skalès: vidinès motyvacijos - malonumo, išorinès motyvacijos - išvaizdos gerinimo ir fizinio tinkamumo. Tiriamuju mankštinimosi motyvacijos stiprumas matyti iš kiekvienoje skaleje surenkamu balų skaičiaus. Šios imties skaliu vidinis suderinamumas buvo geras, atitinkamai Cronbach $\alpha=0,84 ; 0,79$ ir 0,83 .

Nerimas dèl socialinio išvaizdos prièmimo (NSIP) buvo nustatytas Nerimo dèl savo išvaizdos socialinio prièmimo skale (Hart et al., 1989). Skalę sudaro 12 teiginių, rodančių nerimą, kuri gali patirti žmonès, kai jų išvaizda vertinama kitu žmonių. Respondentai vertina kiekvieną teigini Likerto skalëje pasirinkdami atsakymų variantus nuo „Visiškai nesutinku“ (1) iki „Visiškai sutinku“ (5). Aukštesni balai atskleidžia didesnị nerimo lygmeni. Šios imties skalès vidinis suderinamumas buvo geras (Cronbach $\alpha=0,76)$.

Kūno masès indeksas (KMI) apskaičiuotas tiriamiesiems subjektyviai nurodžius ūgi ir svori pagal formulę (svoris $\left.(\mathrm{kg}) / \mathrm{u} g i s(\mathrm{~m})^{2}\right)$.
Tyrimo imtis ir organizavimas. Tyrimas atliktas 11 privačių šalies sveikatingumo klubų, gavus šių klubų vadovų sutikimą. Taikant apklausos raštu metodą, buvo apklausta 244 sveikatingumo centruose besimankštinantys asmenys. Iš jų 27 profesionaliai sportavo, todèl anketos buvo atmestos. Galutinę imti sudarè 217 tiriamujų, iš jų 66 moterys (amžiaus vidurkis — 29,02 $\pm 9,9$ m.). Atrankos i tiriamają imti kriterijus - mankštinimasis ne trumpiau kaip šešis mènesius. Jauniausias tiriamasis buvo 18, vyriausias - 66 metų amžiaus. Anketos pildomos prieš pratybas arba po jų. Užpildytos anketos iš karto surenkamos. Apklausą vykdè išmokytas tyrejjas. Anketinė apklausa buvo vykdoma remiantis geros valios, anonimiškumo ir savanoriškumo principais.

Statistinè analizè. Duomenys buvo analizuojami naudojantis statistinès duomenu analizès programiniu paketu SPSS for Windows 13.0. Kokybinių požymių statistinis ryšys vertintas chi kvadrato kriterijumi. Skirstinių lygybėms tikrinti buvo skaičiuojamas Kruscal ir Wallis H testas. Ryšiams tarp kintamuju nustatyti atlikta koreliacinè analize (skaičiuojamas Spirmeno (Spearman) rho koeficientas). Norint išsiaiškinti, kaip įvairūs veiksniai susiję su maisto papildu vartojimu, buvo taikoma dvinarè žingsninè logistinè regresija (Enter modelis) ir skaičiuojami galimybių santykiai (GS). Rezultatai buvo laikomi statistiškai reikšmingais, jei 1 neįeidavo ị pasikliautinaji intervalą (PI). Visi rezultatai buvo laikomi statistiškai reikšmingais, kai $\mathrm{p}<0,05$.

\section{REZULTATAI}

Iš visos tiriamosios imties maisto papildus, mažinančius kūno masę, vartojo 35 (16,3\%) respondentų. Daugiau moterų negu vyrų vartojo

\begin{tabular}{|l|c|c|l|}
\hline \multicolumn{1}{|c|}{ Kintamieji } & Vyrai $(\mathbf{n}=\mathbf{1 5 1})$ & Moterys $(\mathbf{n}=\mathbf{6 6})$ & \multicolumn{1}{c|}{$\mathbf{p}$} \\
\hline Amžius & 99,58 & 130,55 & $\chi^{2}=11,2 ; \mathrm{df}=1 ; \mathrm{p}=0,001$ \\
\hline Mankštinimosi stažas & 109,82 & 107,13 & $\chi^{2}=0,09 ; \mathrm{df}=1 ; \mathrm{p}=0,77$ \\
\hline ŠKS stiprinimo dažnis & 101,70 & 122,22 & $\chi^{2}=5,75 ; \mathrm{df}=1 ; \mathrm{p}=0,016$ \\
\hline Motyvacija: malonumas & 96,03 & 109,65 & $\chi^{2}=2,30 ; \mathrm{df}=1 ; \mathrm{p}=0,13$ \\
\hline Motyvacija: išvaizda & 95,85 & 114,33 & $\chi^{2}=4,10 ; \mathrm{df}=1 ; \mathrm{p}=0,04$ \\
\hline Motyvacija: fizinis pajëgumas & 97,76 & 117,81 & $\chi^{2}=4,94 ; \mathrm{df}=1 ; \mathrm{p}=0,026$ \\
\hline KMI & 127,49 & 63,02 & $\chi^{2}=48,7 ; \mathrm{df}=1 ; \mathrm{p}<0,001$ \\
\hline NSIP & 91,07 & 134,95 & $\chi^{2}=23,17 ; \mathrm{df}=1 ; \mathrm{p}<0,001$ \\
\hline Tikslas: jëga & 119,12 & 77,48 & $\chi^{2}=39,66 ; \mathrm{df}=1 ; \mathrm{p}<0,001$ \\
\hline Tikslas: raumenų masė & 129,11 & 50,53 & $\chi^{2}=94,43 ; \mathrm{df}=1 ; \mathrm{p}<0,001$ \\
\hline Tikslas: raumenu ištvermé & 113,76 & 92,82 & $\chi^{2}=12,15 ; \mathrm{df}=1 ; \mathrm{p}<0,001$ \\
\hline Tikslas: riebalų mažinimas & 101,61 & 124,52 & $\chi^{2}=11,44 ; \mathrm{df}=1 ; \mathrm{p}=0,001$ \\
\hline Tikslas: ŠKS stiprinimas & 106,05 & 115,74 & $\chi^{2}=4,35 ; \mathrm{df}=1 ; \mathrm{p}=0,037$ \\
\hline Tikslas: lankstumas & 99,87 & 125,79 & $\chi^{2}=15,18 ; \mathrm{df}=1 ; \mathrm{p}<0,001$ \\
\hline
\end{tabular}

1 lentelè. Tyrimo kintamuju rangų (Kruskal-Wallis testas) rodikliai vyru ir moteru grupèse

Pastaba. ŠKS lavinimo daž nis — širdies ir kraujagysliu sistemos stiprinimo dažnis; KMI — kūno masès indeksas; NSIP — nerimas dèl socialinio išvaizdos prièmimo; ŠKS stiprinimas — širdies ir kraujagyslių sistemos stiprinimas. 


\begin{tabular}{|c|c|c|}
\hline \multirow{8}{*}{$\begin{array}{l}2 \text { lentelè. Tyrimo kintamųjų ir kūno } \\
\text { masę mažinančių preparatų vartojimo } \\
\text { koreliacinis ryšys (Spirmeno rho koefi- } \\
\text { cientai) }\end{array}$} & Kintamieji & Spirmeno rho koeficientai \\
\hline & Lytis & $0,17 *$ \\
\hline & Amžius & 0,11 \\
\hline & Mankštinimosi stažas & 0,11 \\
\hline & ŠKS stiprinimo dažnis & 0,08 \\
\hline & Motyvacija: malonumas & 0,04 \\
\hline & Motyvacija: išvaizda & 0,03 \\
\hline & Motyvacija: fizinis pajėgumas & 0,05 \\
\hline \multirow{8}{*}{$\begin{array}{l}\text { Pastaba. } *-\mathrm{p}<0,05 * *-\mathrm{p}<0,01 . \\
\text { Lytis: } 1=\text { vyrai, } 2=\text { moterys; ŠKS sti- } \\
\text { prinimo dažnis — širdies ir kraujagyslių } \\
\text { sistemos stiprinimo dažnis; KMI — kūno } \\
\text { masės indeksas; NSIP — nerimas dèl so- } \\
\text { cialinio išvaizdos prièmimo; ŠKS stipri- } \\
\text { nimas - širdies ir kraujagyslių sistemos } \\
\text { stiprinimas. }\end{array}$} & KMI & 0,10 \\
\hline & NSIP & $0,19 * *$ \\
\hline & Tikslas: jèga & 0,01 \\
\hline & Tikslas: raumenų masé & $-0,15^{*}$ \\
\hline & Tikslas: raumenų ištvermė & 0,03 \\
\hline & Tikslas: riebalų mažinimas & $0,18 *$ \\
\hline & Tikslas: ŠKS stiprinimas & $0,14 *$ \\
\hline & Tikslas: lankstumas & 0,07 \\
\hline
\end{tabular}

šiuos maisto papildus — atitinkamai 17 (25,8\%) ir $18(11,9 \%) \quad\left(\chi^{2}=6,5 ; \mathrm{df}=1 ; \mathrm{p}=0,01\right)$. Medžiagas, deginančias riebalus, per pastaruosius du mėnesius vartojo $10(4,6 \%)$ tiriamujų, iš jų 8 $(5,3 \%)$ vyrai ir $2(3 \%)$ moterys $\left(\chi^{2}=0,54 ; \mathrm{df}=1\right.$; $\mathrm{p}=0,46)$. Kofeiną vartojo taip pat 10 tiriamuju $(4,6 \%)$, iš jų $6(4 \%)$ vyrai ir $4(6,1 \%)$ moterys $\left(\chi^{2}=0,46 ; \mathrm{df}=1 ; \mathrm{p}=0,50\right)$. L-karnitiną vartojo $25(11,5 \%)$ tiriamujų, iš jų $11(7,3 \%)$ vyrų ir 14 $\left(21,2 \%\right.$.) moteru $\left(\chi^{2}=8,73 ; \mathrm{df}=1 ; \mathrm{p}=0,003\right)$. Tik $4(1,8 \%)$ tiriamieji nurode vartojantys kitus maisto papildus, visi jie buvo vyrai. $25(11,5 \%)$ tiriamieji teigè vartojantys tik vieną maisto papildą, kuris mažina kūno masę, tačiau net $10(4,6 \%)$ vartojo du ir daugiau tokių maisto papildų vienu metu.

Atlikus Kolmogorovo-Smirnovo testą paaiškèjo, kad duomenys yra pasiskirstę netolygiai, todèl analizuojant rezultatus buvo taikoma neparametrinių duomenų statistika. Šios imties moterys buvo statistiškai reikšmingai vyresnès (1 lent.), tačiau mankštinimosi stažas lyties atžvilgiu nesiskyrè. Moterys reikšmingai dažniau lankè pratybas, stiprinančias širdies ir kraujagyslių sistemą, dažniau mankštinosi dẻl išoriniu motyvų (išvaizdos ir fizinio pajègumo). Kaip ir buvo tikètasi, vyrų KMI buvo statistiškai reikšmingai didesnis, tačiau moterys išgyveno didesni nerimą dèl socialinio savo išvaizdos prièmimo. Vyrai statistiškai reikšmingai dažniau mankštinosi raumenų jẻgos ir ištvermès bei raumenų masès auginimo tikslais, moterys — dèl riebalų mažinimo, širdies ir kraujagyslių sistemos stiprinimo, riebalų mažinimo ir lankstumo.

Koreliacinė analizè atskleidè, kad moterys dažniau vartoja maisto papildus, mažinančius kūno masę (2 lent.). Amžius nebuvo reikšmingai susijęs su šių papildų vartojimu. Širdies ir kraujagyslių sistemos stiprinimo dažnumas nebuvo susijęs su maisto papildų vartojimo dažnumu. Taip pat nerasta mankštinimosi motyvų ir papildų vartojimo dažnumo sąsajų. Didesnè kūno mase nebuvo reikšmingai susijusi su maisto papildų vartojimo dažnumu, tačiau nerimas dèl savo išvaizdos buvo silpnai, tačiau statistiškai reikšmingai susijęs su minètu elgesiu. Kaip ir tikètasi, aptiktas atvirkštinis silpnas, bet reikšmingas ryšys tarp maisto papildų, mažinančių kūno masę, vartojimo ir raumenu masès didinimo tikslo, silpnas ir statistiškai reikšmingas teigiamas ryšys tarp riebalų mažinimo, širdies bei kraujagysliu sistemos stiprinimo tikslų bei maisto papildu vartojimo (2 lent.).

Ilgesnis mankštinimosi stažas reikšmingai susijęs vidine motyvacija, didesniu KMI ir dažnesniu riebalų mažinimo tikslu (3 lent.). Širdies ir kraujagyslių sistemą stiprinančiu pratybų dažnis nebuvo susijęs su riebalų mažinimo tikslais, o silpnai, bet reikšmingai — su lankstumo lavinimo tikslais. Malonumo motyvas susijęs su visais pratybų tikslais, išskyrus raumenu ištvermès ir masès. Mankštinimasis dèl išvaizdos silpnai, tačiau statistiškai reikšmingai susijęs su nerimu dèl savo išvaizdos ir riebalų mažinimo tikslu. Fizinio pajejgumo gerinimo motyvas taip pat buvo susijęs su didesniu nerimu dẻl savo išvaizdos ir riebalu mažinimo, su širdies ir kraujagyslių sistemos stiprinimo bei lankstumo lavinimo tikslais. Didesnis KMI buvo susijęs su mažesniu nerimu dèl savo išvaizdos, dažnesniu tikslu didinti raumenų masę ir mažinti riebalų kiekị. Didesnis NSIP buvo susijęs su mažesniu nusiteikimu lavinti raumenų jèga ir masę (3 lent.). 
3 lentelè. Koreliacijos (Spirmeno rho) koeficientai tarp tyrimo kintamųjų

\begin{tabular}{|c|c|c|c|c|c|c|c|c|c|c|c|c|c|c|}
\hline Kintamieji & 1 & 2 & 3 & 4 & 5 & 6 & 7 & 8 & 9 & 10 & 11 & 12 & 13 & 14 \\
\hline Lytis & 1 & & & & & & & & & & & & & \\
\hline Mankštinimosi stažas & $-0,02$ & 1 & & & & & & & & & & & & \\
\hline ŠKS stiprinimo dažnis & $0,16^{*}$ & $-0,05$ & 1 & & & & & & & & & & & \\
\hline $\begin{array}{l}\text { Motyvacija: } \\
\text { malonumas }\end{array}$ & 0,11 & $0,14^{*}$ & 0,14 & 1 & & & & & & & & & & \\
\hline Motyvacija: išvaizda & $0,14^{*}$ & $-0,09$ & 0,02 & $0,34 * *$ & 1 & & & & & & & & & \\
\hline $\begin{array}{l}\text { Motyvacija: fizinis } \\
\text { pajègumas }\end{array}$ & $0,16^{*}$ & 0,006 & 0,10 & $0,52 * *$ & $0,42 * *$ & 1 & & & & & & & & \\
\hline KMI & $-0,48 * *$ & $0,29 * *$ & $-0,11$ & $-0,03$ & $-0,06$ & 0,09 & 1 & & & & & & & \\
\hline NSIP & $0,34 * *$ & 0,006 & 0,07 & 0,13 & $0,29 * *$ & $0,17^{*}$ & $-0,24 * *$ & 1 & & & & & & \\
\hline Tikslas: jèga & $-0,43 * *$ & $-0,05$ & $-0,01$ & $0,17^{*}$ & $-0,07$ & 0,01 & 0,12 & $-0,26^{* *}$ & 1 & & & & & \\
\hline $\begin{array}{l}\text { Tikslas: raumenų } \\
\text { masé }\end{array}$ & $-0,67 * *$ & 0,07 & $-0,16^{*}$ & 0,05 & 0,05 & $-0,05$ & $0,27 * *$ & $-0,29 * *$ & $0,56^{* *}$ & 1 & & & & \\
\hline $\begin{array}{l}\text { Tikslas: raumenų } \\
\text { ištvermé }\end{array}$ & $-0,24 * *$ & $-0,11$ & 0,02 & 0,13 & 0,06 & 0,12 & 0,05 & $-0,10$ & $0,40^{* *}$ & $0,32 * *$ & 1 & & & \\
\hline $\begin{array}{l}\text { Tikslas: riebalu } \\
\text { mažinimas }\end{array}$ & $0,23 * *$ & $0,18^{* *}$ & 0,11 & $0,16^{*}$ & $0,18^{*}$ & $0,20 * *$ & $0,28 * *$ & 0,10 & $-0,12$ & $-0,20 * *$ & $-0,03$ & 1 & & \\
\hline $\begin{array}{l}\text { Tikslas: ŠKS } \\
\text { stiprinimas }\end{array}$ & $0,14^{*}$ & 0,05 & $0,16^{*}$ & $0,15^{*}$ & $-0,04$ & $0,34 * *$ & $0,15^{*}$ & 0,06 & $-0,05$ & $-0,18^{* *}$ & 0,11 & $0,30 * *$ & 1 & \\
\hline Tikslas: lankstumas & $0,27 * *$ & 0,002 & $0,21 * *$ & $0,15^{*}$ & 0,03 & $0,26 * *$ & $-0,01$ & 0,08 & $-0,09$ & $-0,23 * *$ & $-0,01$ & $0,35 * *$ & $0,45 * *$ & 1 \\
\hline
\end{tabular}

Pastaba. $*-p<0,05, \quad * *-p<0,01$. Lytis: $1=$ vyrai, $2=$ moterys; ŠKS stiprinimo dažnis — širdies ir kraujagysliu sistemos stiprinimo dažnis; KMI — kūno masès indeksas; NSIP — nerimas dèl socialinio išvaizdos priẻmimo; ŠKS stiprinimas — širdies ir kraujagyslių sistemos stiprinimas.

\begin{tabular}{|l|c|c|c|c|}
\hline & B & GS & \multicolumn{2}{|c|}{ PI } \\
\hline $\mathbf{1}$ modelis (Nagerkelke $\left.R^{2}=0,05\right)$ & 0,99 & 2,70 & 1,26 & 5,78 \\
\hline Lytis & \multicolumn{5}{|l|}{} \\
\hline $\mathbf{2}$ modelis (Nagerkelke $\left.R^{2}=0,10\right)$ & 0,66 & 1,93 & 0,85 & 4,39 \\
\hline Lytis & 0,75 & 2,12 & 1,13 & 3,96 \\
\hline NSIP & 0,47 & 1,59 & 0,69 & 3,68 \\
\hline 3 modelis (Nagerkelke $\left.R^{2}=0,14\right)$ \\
\hline Lytis & 0,72 & 2,05 & 1,10 & 3,82 \\
\hline NSIP & 1,29 & 3,62 & 0,97 & 13,53 \\
\hline Tikslas: riebalų mažinimas &
\end{tabular}

4 lentelè. Analizuojamų veiksnių galimybių santykiai (GS) ir jų pasikliautinieji intervalai (PI) prognozuojant maisto papildų, mažinančių kūno masę, vartojimą

Pastaba. Lytis užkoduota: 1 = moterys, 2 = vyrai; NSIP — nerimas dèl socialinio išvaizdos prièmimo.
Norèdami išsiaiškinti, koks veiksnių kompleksas labiausiai paaiškina kūno masę mažinančių maisto papildų vartojimą, pasitelkème dvinarę žingsninę logistinę regresiją (4 lent.). Atlikdami šią regresiją, stengèmès kontroliuoti lyties efektą. Pirmiausia, kaip ir tikèjomès, išaiškejjo, kad moterys statistiškai reikšmingai tris kartus didina maisto papildų, mažinančių kūno masę, vartojimo tikimybę. Tačiau kitu modeliu ịvedus nerimo dèl savo išvaizdos socialinio prièmimo kintamaji, lyties efektas pasidare statistiškai nereikšmingas, o modelio pseudo $R^{2}$ padidejo iki 0,10 . Galutiniame modelyje ivvedus mankštinimosi dèl riebalų mažinimo kintamaji, pseudo $R^{2}$ padidèjo iki 0,14 , o nerimas dèl socialinio išvaizdos prièmimo išliko stipriausiu maisto papildų vartojimą skatinančiu veiksniu. Lyties efektas ir toliau išliko statistiškai nereikšmingas, o riebalų mažinimo tikslas daugiau nei tris kartus beveik statistiškai reikšmingai didino maisto papildų vartojimo tikimybę.

\section{REZULTATŲ APTARIMAS}

Šiuo tyrimu norejome nustatyti sveikatingumo centruose besimankštinančių asmenų maisto papildų, mažinančių kūno masę, vartojimo paplitimą ir atlikti susijusių veiksnių analizę. Mūsų tyrimo metu maisto papildus vartojo 16\% respondentų. Panašų skaičių nurodo ir JAV atlikti populiaciniai tyrimai, kuriais nustatyta, kad maisto papildus, mažinančius kūno masę, vartoja 7-33,9\% tiriamujų (Blanck et al., 2001; Blank 2007; Pilliteri et al., 2008). Analogiškų tyrimų su besimankštinančiujuc imtimis aptikti nepavyko, nors nustatyta, kad kofeiną, kuris padeda mažinti svori, vartojo pusé sveikatingumo centru sportuotojų (Sheppard et al., 2000), o mūsų tyrimo metu - vos $4,6 \%$ asmenų. Šis skirtumas gali būti aiškinamas kultūriniais, klientu informuotumo, KMI ir požiūrio ỉ kūno masès kontrolę skirtumais. 
Šiuo tyrimu kèlème prielaidą, kad kūno masę mažinančius papildus dažniau vartos moterys, daugiau jaunesni besimankštinantys, kurie tai daro dèl išvaizdos gerinimo motyvų, ir norintys sumažinti riebalų kiekį. Šioji prielaida patvirtinta iš dalies - moterys dažniau vartojo maisto papildus. Tai sutampa ir su kitų autorių duomenimis (Pilliteri et al., 2008; Blank et al., 2009). Antroji prielaidos dalis nepasitvirtino - amžius nebuvo susijęs su šių papildų vartojimu. Kaip ir buvo tikètasi, maisto papildus, kurie mažina kūno svorị, dažniau vartojo tie asmenys, kurių vienas iš pagrindinių mankštinimosi tikslų - mažinti riebalų kieki.

Širdies ir kraujagysliu sistemos stiprinimo tikslo dažnumas nebuvo susijęs su maisto papildu vartojimo dažnumu. Taip pat analizè atskleide, kad asmenys, kurių mankštinimosi tikslas — riebalų masès mažinimas nėra linkę dažniau užsiimti aerobine veikla, stiprinančia širdies ir kraujagyslių sistemą bei padedančia mažinti riebalini audini. Tai rodo, kad dalies besimankštinančiuju tikslai ir elgesys nevisiškai sutampa. Tikèjomès, kad asmenys, norintys mažinti kūno masę, dažniau imsis aerobinès veiklos. Deja, tyrimas atskleide, kad jie dažniau vartoja maisto papildus, mažinančius kūno masę. Tyrimas verčia atkreipti dèmesi i tai, kad dalies besimankštinančiujų elgesys, kontroliuojant kūno masę, gali būti žalingas sveikatai. Analogiškų tyrimų aptikti nepavyko. Ko gero, ši problema yra mažai tyrinèta arba egzistuoja tik mūsų šalies sveikatingumo centruose, todèl tyrimų duomenis reikètų patikrinti kitomis studijomis.

Kaip ir tikètasi, ilgesnis mankštinimosi stažas buvo reikšmingai susijęs vidine motyvacija. Tai sutampa su apsisprendimo motyvacijos teorine prielaida, teigiančia, kad vidinè motyvacija susijusi su tikimybe tęsti tam tikrą veiklą ilgiau (Ryan, Deci, 2000). Nustatyta tendencija, kad mankštinimasis dèl malonumo mažino maisto papildų, kurie mažina kūno masę, vartojimo tikimybę. Tai paaiškina besimankštinančiojo orientacija i vidinius (pasitenkinimo), o ne išorinius (tiesiogiai nesusijusius su mankštinimusi, pvz., išvaizdos kontrolès) tikslus.

Mankštinimasis dèl išvaizdos silpnai, tačiau statistiškai reikšmingai susijęs su NSIP ir riebalu mažinimo tikslu. Kitų autorių tyrimo rezultatai panašūs (Sabiston et al., 2005). Idomu tai, kad fizinio pajègumo gerinimo motyvas taip pat buvo susijęs su didesniu NSIP ir riebalų mažinimo, su širdies ir kraujagyslių sistemos stiprinimo bei lankstumo lavinimo tikslais. Vadinasi, fizinio pajëgumo motyvą sunku priskirti vien tik išorinès ar vidinès motyvacijos rūšiai, nes jame persipina išorinis išvaizdos gerinimo ir vidinis sveikatingumo komponentai.

Antroji prielaida visiškai pasitvirtino - NSIP buvo susijęs su dažnesniu maisto papildų vartojimu. KMI nebuvo susijęs su dažnesniu maisto papildų vartojimu, tačiau NSIP šią tikimybę didino dvigubai. Lytis taip pat nebuvo pačiu stipriausiu maisto papildų vartojimą nusakančiu veiksniu kontroliuojant lyties efektą, stipriausiu veiksniu galutiniame modelyje išliko NSIP. Taigi besimankštinantieji, nepriklausomai nuo lyties, linkę dažniau vartoti kūno masę mažinančius papildus, jeigu jie patiria didesnį nerimą dèl socialinio savo išvaizdos prièmimo. Kiti tyrimai atskleidžia, kad NSIP susijęs su valgymo patologija (Diehl et al., 1998), o maisto papildų, kurie mažina kūno masę, vartojimas dažnai laikomas vienu iš sutrikusio valgymo požymių (Neumark-Sztainer et al., 2006). Kadangi analogiškų tyrimų aptikti nepavyko, tai gautus duomenis taip pat reikètų tikrinti tolesniais tyrimais.

Ilgesnis mankštinimosi stažas nebuvo reikšmingai susijęs su dažnesniu kūno masę mažinančių maisto papildu vartojimu. Vadinasi, ilgiau besimankštinantys asmenys nèra labiau spaudžiami vartoti maisto papildus, nors iš praktikos žinoma, kad prekyba maisto papildais yra papildomas trenerių ir instruktorių pajamų šaltinis.

Pagrindinis tyrimo trūkumas — ne atsitiktinè ir nedidele tyrimo imtis, todèl tyrimo duomenų negalima apibendrinti kaip visos besimankštinančiuju populiacijos. Taip pat tirta mažai moterų, todèl tolesnių tyrimų metu verta apklausti gausesnę imti. Stiprioji tyrimo pusè - daugiakomponentis tyrimo modelis, patikimas klausimynas.

\section{IŠVADOS}

Maisto papildus, kurie mažina kūno masę, vartoja $16 \%$ besimankštinančiujų. Šiuos maisto papildus dažniau vartoja moterys. Nerimo dèl socialinio išvaizdos prièmimo ir riebalų mažinimo tikslas, nepriklausomai nuo lyties, prognozuoja didesnę maisto papildų, mažinančių kūno masę, vartojimą. Besimankštinančių asmenų kūno masẻ kontroliuojama sveikatai žalingu būdu, todèl būtina stiprinti tokio elgesio prevenciją sveikatingumo centruose ir klubuose. 


\section{LITERATŪRA}

Atkinson, M. (2007). Playing with fire: Masculinity, health, and sports supplements. Sociology of Sport Journal, $24,165-186$.

Ayranci, U., Son, N., Son, O. (2005). Prevalence of nonvitamin, nonmineral supplement usage among students in a Turkish university. BMC Public Health, 5 (47). Prieiga internetu: Doi10.1186/1471-2458-5-47.

Blank, H. M., Khan, L. K., Serdula, M. K. (2001). Use of nonpresciption weight loss products. Journal of American Medicine Association, 286, 930-935.

Blank, H. M., Serdula, M. K., Gillespie, C. et al. (2007). Use of nonprescription dietary supplements for weight loss in common among Americans. Journal of the American Dietetic Association, 107 (3), 441-447.

Castillo, E. M., Hurtado, S. L., Shaffer, R. A., Rock, Ch. L., Brodine, S. K. (2002). Dietary supplement use in a physically active population. Naval Health Research Center San Diego CA. Prieiga internetu: http://handle.dtic.mil/100.2/ ADA419671

Diehl, N. S., Johnson, C. E., Rogers, R. L., Petrie, T. A. (1998). Social physique anxiety and disordered eating: What's the connection? Addictive Behaviors, 23 (1), $1-6$.

Dominques, S. F., Marins, J. C. B. (2007). Ergogenic aids and nutritional supplement use among resistance training practioner in Belo Horizonte - MG. Fitness Performance, $6(4), 218-226$.

Field, A. E., Austin, S. B., Camargo, C. A. et al. (2005). Exposure to the mass media, body shape concerns and use of supplements to improve weight and shape among male and female adolescents. Pediatrics, 116, 214-220.

Frederick, C. M., Ryan, R. M. (1993). Differences in motivation for sport and exercise and their relationships with participation and mental health. Journal of Sport Behaviour, 6, 125-145.

Froiland, K., Koszewski, W., Hingst, J., Kopecky, L. (2004). Nutritional supplement use among college athletes and their sources of information. International Journal of Sport Nutrition and Exercise Metabolism, 14, 104-120.

Grunewald, K. K., Bailey, R. S. (1993). Commercially marketed supplements for bodybuilding athletes. Sports Medicine, 15 (2), 90-103.

Hart, E. H., Leary, M. R., Rejeski, W. J. (1989). The measurement of social physique anxiety. Journal of Sport and Exercise Psychology, 11, 94-104.

Kanayama, G., Gruber, A. J., Pope, H. G., Borowiecki, J. J., Hudson, J. I. (2001). Over-the-counter drug use in gymnasiums: An underrecognized substance abuse problem? Psychotherapy and Psychosomatics, 70, 137-140.
Kristiansen, M., Levy-Milne, R., Barr, S., Flint, A. (2005). Dietary supplement use by varsity athletes at a Canadian university. International Journal of Sport Nutrition and Exercise Metabolism, 15, 195-210.

Lenz, T. L., Hamilton, W. R. (2004). Supplemental products used for weight loss. Journal of the American Pharmacists Association, 44 (1), 59-68.

Lutz, R., Arent, S. (2009). Psychology of supplementation in sport and exercise. Motivational antecedents and biobehavioral outcomes. In Nutritional Supplements in Sports and Exercise. Humana Press.

Neumark-Sztainer, D., Wall, M., Guo, J. et al. (2006). Obesity, disordered eating, and eating disorders in a longitudinal study of adolescents: How do dieters fare 5 years later? Journal of the American Dietetic Association, 106 (4), 559-565

Philen, R. M., Ortiz, D., Auerbach, S. B., Falk, H. (1992). Survey of advertising for nutritional supplements in health and bodybuilding magazines. Journal of American Medical Association, 268 (8), 1006-1011.

Pillitteri, J. L., Shiffman, S., Rohay, J. M. et al. (2008). Use of dietary supplements for weight loss in the United States: Results of a National Survey. Obesity, 16 (4), 790-796.

Pittler, M. H., Schmidt, K., Ernst, E. (2005). Adverse events of herbal food supplements for body weight reduction: Systematic review. Obesity Reviews, 6, 93-111.

Raudenbush, B., Meyer, B. (2003). Muscular dissatisfaction and supplement use among male intercollegiate athletes. Journal of Sport and Exercise Psychology, 25, $171-187$.

Reinert, A., Rohrmann, S., Becker, N., Linseisen, J. (2007). Lifestyle and diet in people using dietary supplements. European Journal of Health Nutrition, 46, 165-173.

Ryan, R. M., Deci, E. L. (2000). Self-determination theory and the facilitation on intrinsic motivation, social development, and well-being. The American Psychologist, 5, $68-78$

Sabiston, C. M., Crocker, P. R. E., Munroe-Chandler, K. J. (2005). Examining current - ideal discrepancy scores and exercise motivations as predictors of social physique anxiety in exercising females. Journal of Sport Behavior, $28,68-85$

Sheppard, H. L., Raichada, S. M., Kouri, K. M., StensonBar-Maor, L., Branch, D. (2000). Use of creatine and other supplements by members of civilian and military health clubs: A cross - sectional survey. International Journal of Sport Nutrition and Exercise Metabolism, 10, 245-259. 


\title{
THE USE OF WEIGHT LOSS SUPPLEMENTS AND THE ANALYSIS OF THE RELATED FACTORS AMONG THE MEMBERS OF FITNESS CENTRES
}

\author{
Rasa Jankauskienè, Ramutis Kairaitis \\ Lithuanian Academy of Physical Education, Kaunas, Lithuania
}

\begin{abstract}
The use of weight loss supplements (WLS) might be risky behaviour because of the lack of scientific evidence about the effectiveness and safety of these products. Despite this fact, $7-33 \%$ of Americans reported using weight loss supplements. The prevalence of the use of WLS in exercising populations is unclear, yet some studies showed that every second fitness anhe member used caffeine supplement. There is a lack of studies reporting the prevalence of WLS use, moreover less is known about the relationships between WLS use and exercise motivation, exercise goals and social physique anxiety (SPA).

The aim of this study was to assess the use of WLS in fitness centres exercising persons and to analyse the relationships with exercise related factors and SPA.

The study was carried out in 11 local health and fitness centres. The data were collected using the method of anonymous questioning. The sample consisted of 217 respondents, 66 of them were women (mean age $-29.02 \pm 9.9$ years). The demographic data, exercise - related and WLS use - related data were collected. Exercise motives were assessed by Motives for Physical Activity Measure - Revised, MPAM - R questionnaire (Frederick, Ryan, 1993). Social physique anxiety was assessed using Social Physique Anxiety Scale (Hart et al., 1989).

$16,3 \%$ of the exercisering persons reported having used WLS in the past for 2 months, and there were more women compared to men $(\mathrm{p}=0.01)$. Logistic regression showed that controlling gender, SPA and training goals to reduce body weight were predictors of WLS $(\mathrm{p}<0.05)$. Conclusions. WLS use might be health damaging factors for fitness centre members. Prevention of such behaviour should be enhanced. SPA should be reduced and the internal exercise motivation should be enhanced to prevent using WLS use. The results should not be generalized to overall exercising population, the findings should be supported by other studies.
\end{abstract} anxiety.

Keywords: the use of weight loss supplements, exercise motives, exercise goals, social physique

Rasa Jankauskienè

Priimta $2010 \mathrm{~m}$. vasario $4 \mathrm{~d}$.

Acceptedon February 4, 2010
Lietuvos kūno kultūros akademija

(Lithuanian Academy of Physical Education)

Sporto g. 6, LT-44221 Kaunas

Lietuva (Lithuania)

Tel +370 37302638

E-mail r.jankauskiene@lkka.1t 